\section{Uso de três fontes de dados altimétricos para identificação de áreas com perigos à inundação}

Bruno Zucuni Prina*

Romário Trentin**
Resumo: Esse trabalho possui o intuito de realizar um mapeamento das áreas de perigo à inundação no município de Jaguari/RS, com três distintas fontes de dados altimétricos: cartas topográficas do exército, uma cena do SRTM e uma imagem orbital do ASTER. Com isso, criaram-se inúmeras bases cartográficas no aplicativo ArcGIS ${ }^{\circ}$ (MDE, mapa urbano, mapa de densidade urbana, mapa de declividade e mapa de buffer) e posteriormente, os referidos dados foram modelados com a atribuição de "pesos" e "notas" no aplicativo Vista Saga, a fim de estimar o perigo à inundação no município. A partir da modelagem dos dados, identificou-se que os dados do SRTM e ASTER resultaram em uma melhor representação das áreas de perigo à inundação, fato que pode ser complementado pela alta correlação dos dados $\left(\mathrm{R}^{2}=0,931\right)$ de ambos. A partir dessa modelagem, identificaram-se as áreas que resultaram em "alto perigo à inundação", composta pelos bairros: Centro, Mauá, Nossa Senhora Aparecida, Promorar, Rivera e Sagrado Coração de Jesus. Esses bairros, em futuros trabalhos, serão os que receberão atenção especial para coletadas de dados in loco.

\section{Use of three sources of altimetric data for identification of flood hazards} areas

\begin{abstract}
This paper has the objective of perform mapping of the flood hazard areas in the city of Jaguari/ Brazil, using three different bases of elevation data: topographic maps of the army, an image of the SRTM and an image of ASTER. With this, were constructed various cartographic databases the application ArcGIS ${ }^{\circledR}$ (DEM, urban map of urban density map, slope map and buffer map) and later, data were modeled by assigning "weights" and "notes" in Vista Saga application, to estimate the hazard of flooding in the city. From the modeling of the data, was identified that data from the SRTM and ASTER resulted in a better representation of the flood hazard areas, fact that can be complemented for high data correlation $\left(\mathrm{R}^{2}=\right.$ 0.931). From this modeling, were identified areas resulting in "high hazard flood", composed of the neighborhoods: Centro, Mauá, Nossa Senhora Aparecida, Promorar, Rivera e Sagrado Coração de Jesus. These neighborhoods, in future studies, will be those who will receive special attention to data collected in situ.
\end{abstract}

* Tecnólogo em Geomática pela Universidade Federal de Santa Maria (UFSM). Mestrando no Programa de Pós Graduação em Geografia na mesma universidade.

** Doutor em Geografia pela Universidade Federal do Paraná. Professor Adjunto no Departamento de Geografia da UFSM

\section{Palavras-chave:}

Inundação,

SRTM, ASTER, Carta Topográfica, Suscetibilidade, Perigo.

\section{Key-Words:}

Flooding, SRTM, ASTER, Topographic Susceptible, Hazard. 


\section{Introdução}

No Brasil não há incidência de desastres naturais de origem tectônica, contudo, Santos (2007, p. 10) alerta que em nosso país "os desastres tendem a estar relacionados a fenômenos climáticos, potencializados pela ação do homem”. Segundo dados descritos pelo mesmo autor, no período de 2000 a 2007 foram registrados cerca de 36 grandes episódios de desastres naturais (enchentes, secas e deslizamentos de terra) no Brasil, com mais de 1,5 milhões de pessoas afetadas, estimando ao país um prejuízo econômico na ordem de US\$ 2,5 bilhões ${ }^{1}$. Uma sucinta explicação para os grandes prejuízos no país é apresentada por Santos (2007, p. 11) que destaca que "o uso impróprio dos recursos naturais, a ocupação de áreas com maior suscetibilidade natural e o desmatamento são, no Brasil, os principais fatores que potencializam a ocorrência de desastres naturais".

Destarte, nesse trabalho realizou-se um mapeamento a fim de pré-identificar ${ }^{2}$ os locais com maiores graus de perigo à inundação no município de Jaguari/RS (Figura 1). Assim, utilizaram-se os aplicativos: ArcGIS® (para gerar os mapas) e o Vista Saga (para realizar o cruzamento espacial). Para geração dos mapas, foi utilizado três fontes de dados altimétricos: cartas topográficas, uma cena do Shuttle Radar Topographic Mission (SRTM) e uma imagem orbital do Advanced Spaceborne Thermal Emission and Reflection Radiometer (ASTER).

Figura 1 - Mapa de localização.

${ }^{1}$ Base de dados que Santos (2007) obteve por meio da Universidade Católica de Louvain, Bélgica.

${ }^{2}$ Utilizou-se a terminologia "pré-identificar" pelo fato de que o referido trabalho será composto por dados altimétricos não coletados a campo, assim, as estimativas serão aproximadas.
Geografia Ensino \& Pesquisa, v. 18, n.2, p. 123-144, maio/ago. 2014.

Uso de três fontes de dados altimétricos para identificação de áreas com perigos à inundação

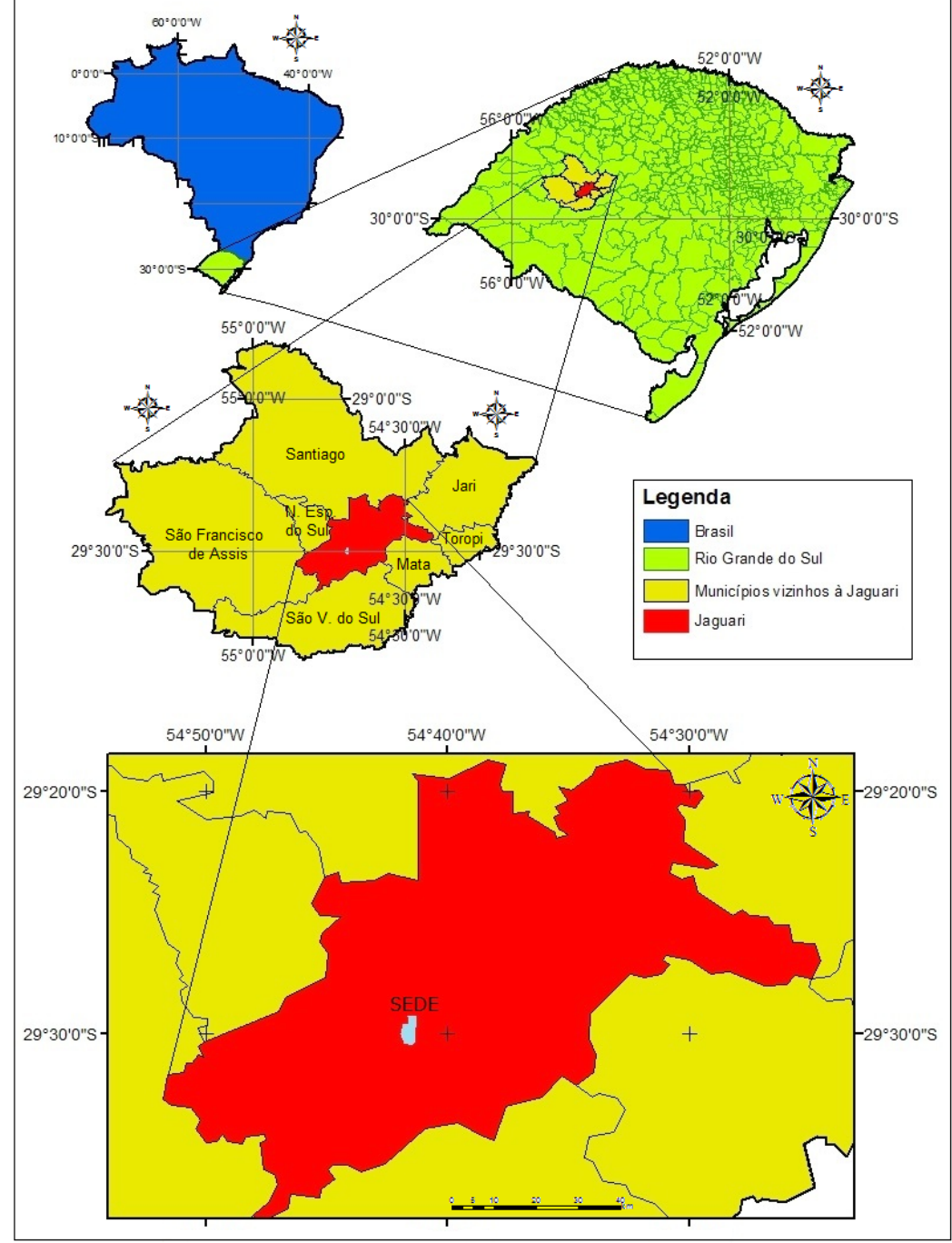

Fonte: organizado pelos autores. 
Como o foco do trabalho é realizar a identificação de áreas inundáveis, foram confeccionados os mapas de suscetibilidade (MDE), de declividade (origem do MDE), urbano, de densidade urbana e de buffer a fim de melhor identificar os locais com maiores perigos. Destaca-se que o incentivo do trabalho está no fato de mapear os locais com distintas classes de perigo, para posteriormente realizar um levantamento planialtimétrico com utilização de métodos topográficos (estação total) e geodésicos (GlobalNavigation Satellite System - GNSS) juntamente com o cadastral, para mapear a vulnerabilidade das construções. Assim, esse trabalho é de extrema importância, pelo fato de que o mesmo orientará na identificação dos locais com maiores probabilidades à inundação no município de Jaguari, norteando as etapas posteriores de coleta de dados in loco.

O município de Jaguari está localizado no centro-oeste do estado do Rio Grande do Sul, sendo banhado pelo Rio Jaguari”, afluente do Ibicuí e é conhecida como "A Cidade das Belezas Naturais", tem essa denominação devido seu povo hospitaleiro, na qual, preserva muito bem as diversas belezas naturais que ali possui (PRINA e MIOLA, 2011).

Em relação ao município de Jaguari, enfatiza-se que a população total é de cerca de 11,5 mil habitantes, numa área territorial de aproximadamente $673 \mathrm{~km}^{2}$, resultando numa densidade demográfica de 17,04 habitantes $/ \mathrm{km}^{2}{ }^{4}$. Em relação a população residente do município de Jaguari, $57 \%$ dos habitantes estão localizados no meio urbano, e 43\% no perímetro rural 5 .

Conforme o levantamento realizado por Reckziegel (2007) entre 1980 e 2005, o município de Jaguari registrou 3 ocorrências de enchentes, sendo elas em: outubro/1982, outubro/1997 e abril/1998. A mesma autora, quantificou, no mesmo período 3 cenários de enxurradas, registradas em: maio/1984, novembro/1997 e outubro/2002. A fim de salientar os problemas com inundações em Jaguari, Reckziegel (2007, p. 136) enfatiza que em 1984, mais especificamente em maio, “os danos mais significativos ocorreram em municípios dos vales dos rios Jaguari e Ibicuí e da porção oeste do estado". A referida autora destaca que mais de 100 edificações ficaram completamente destruídas e aproximadamente 150 ficaram danificadas, ocasionando 2 mortes, além de cerca de 1500 desabrigados no município. Outro grande evento que prejudicou a cidade ocorreu em 1997, mais precisamente em outubro, desabrigando cerca de 890 pessoas (RECKZIEGEL, 2007).

Após o ano de 2005, o qual é limítrofe do trabalho realizado por Reckziegel (2007), o município de Jaguari sofreu, ainda, com dois eventos de inundações. A primeira em janeiro de 2010 e, posteriormente, em outubro de 2012.

Tais registros são comprovados por relatos contabilizados pela mídia. Na primeira data, o jornal Correio do Povo destaca que cerca de 30 famílias ficaram desabrigadas perante o evento. Já na segunda data, diante dos relatos do jornal Diário de Santa Maria (apud NEMITZ, 2012) alguns moradores foram removidos de suas residências, pelo fato de que a água invadiu-as. Assim, fica visível o problema que o município possui em vivenciar cenários de perdas perante as inundações que ali ocorrem.

No que tange ao assunto, a fim de comprovar a importância do referido trabalho, tem-se através do sítio da Agência Nacional de Águas (ANA), com o "Atlas de vulnerabilidade a inundações", no estado do Rio Grande do Sul, que o trecho do Rio Jaguari, que passa pelo meio do perímetro urbano do município, possui a classificação de “alta vulnerabilidade a inundações”. Já, Robaina e Trentin (2013) classificaram Jaguari como sendo um município com média probabilidade de ocorrências de enchentes, assim, faz-se necessário a identificação e mapeamento dos locais com maiores graus de perigo à inundação.

Para o entendimento desse trabalho deve-se de haver a fundamentação teórica de alguns conceitos intrínsecos as questões metodológicas a serem aqui implantadas. Assim sendo, inicialmente haverá a definição do vocábulo "inundação", o qual pode ser definido a partir da discussão de Eckhardt (2008, p. 26 e 27):

(...) inundação é o termo utilizado para o excesso do volume de água que não consegue ser drenado pelo canal principal (leito menor), inundando as áreas ribeirinhas (leito maior ou planície de inundação), de acordo com a topografia e que abrigam vias de circulação e transporte, áreas residenciais, recreativas, comerciais e industriais.
3 "Jaguar-hy" é de origem indígena, significando "rio do jaguar” (FAMURS, s. d.).

4 Disponível em: <http:// w w w. ib ge.gov.br/ cidadesat/xtras/perfil. php? $\operatorname{cod} \operatorname{mun}=431110>$. Acesso em 24 nov.2013.

5 Disponível em: <http:// cidades.ibge.gov.br/xtras/ temas.php?codmun $=43111$ $0 \&$ id tem $a=1 \&$ search $=$ rio grande-do-sul|jaguari|censodemografico-2010:-sinopse->. Acesso em 24 nov.2013.

Geografia Ensino \& Pesquisa, v. 18, n.2, p. 123-144, maio/ago. 2014

Prina, B. Z.; Trentin, R.

ISSN 2236-4994 
Tucci e Bertoni (2003) explicitam que as inundações são integradas a dois processos distintos, os quais ocorrem de forma integrada ou também de forma separada, as quais são as inundações, ocorridas devido à urbanização ou de origem natural (localizadas nas áreas de várzeas). Tais inundações ocorrem tanto no meio urbano como no rural. Sequencialmente serão contextualizados algumas definições que são os pilares, para que sejam constatados, com acurácia, alguns procedimentos metodológicos desse trabalho. Assim, destacar-se-ão os conceitos de suscetibilidade e perigo interligado às inundações.

A terminologia suscetibilidade pode ser conceituada como a possibilidade de que um determinado evento possa ocorrer. Tais fenômenos podem ser qualificados como os relacionados a perdas e danos ao ser humano. A forma em que a suscetibilidade é mapeada depende muito das características naturais da área de estudo, pois, estas são específicas do local (SANTOS, 2012).

A nomenclatura perigo, também é conhecida como haz̧ard (do inglês), a qual é definida como uma fonte ou situação potencial de causar alguma lesão ou doença, danos ao meio ambiente, bem como a combinação dos dois (MAGNANELLI, 2012). Cutter e Press (2001) definem hazard como sendo um indício de ameaça às pessoas, bem como de seus objetos, e enfatizam que existem dois tipos de perigos: os naturais (como os terremotos) e os tecnológicos (provocados por acidentes químicos). Os mapas de perigo são importantes para o planejamento de atividades de desenvolvimento, para planejamento de emergência e para desenvolvimento de políticas (JHA e LAMOND, 2012). Nesse trabalho, o perigo será segmentado em várias classes, sendo que os locais com maior perigosidade serão os que unirem, principalmente, a maior suscetibilidade (as menores cotas altimétricas do terreno) aos locais com ocupação urbana. Resumidamente, a explicação de perigo referenciada por Robaina e Trentin (2013) resume o conceito a aqui ser adotado: "estar em perigo é estar ameaçado de sofrer alguma perda ou dano".

Ainda, é importante referenciar as definições de vulnerabilidade e risco, pois os mapas oriundos dessas duas definições serão modelados em etapas posteriores, por meio de um levantamento cadastral, topográfico e geodésico.

Resumidamente, pode-se conceituar o termo vulnerabilidade como sendo a fragilidade de um sistema ambiental em relação a uma determinada pressão (FIGUEIRÊDO et al, 2010). Esse conceito pode ser englobado conforme o grau de desenvolvimento (pobreza) de uma determinada população (SANTOS, 2007).

Destaca-se que risco (ou do inglês Risk) pode ser oriundo da interação de um perigo (que é um evento não controlável) com uma exposição (que é um evento controlável) (MAGNANELLI, 2012). Cutter e Press (2001) associam a definição de risco como sendo a probabilidade de ocorrência de determinado evento (de acontecer um perigo). Ainda Cutter e Press (2001) enfatizam que o mapeamento e a definição de distintas classes de riscos são importantes pelo fato de que elas definem as áreas de segurança e aceitabilidade, resultando, dessa forma, nos locais apropriados à moradia. Os mapas de risco à inundação incorporam informações dentro do contexto de dados sobre ativos à população, e sua vulnerabilidade ao perigo, bem como sendo uma ferramenta suplementar à tomada de decisão (JHA e LAMOND, 2012).

Destarte, o referido trabalho passar-se-á pela geração de mapas de suscetibilidade e de declividade, através da comparação dos dados altimétricos de cartas topográficas na escala

Geografia Ensino \& Pesquisa, v. 18, n.2, p. 123-144, maio/ago. 2014.

Uso de três fontes de dados altimétricos para identificação de áreas com perigos à inundação 1:50.000, e imagens dos sensores SRTM e ASTER. Com esses, serão cruzados, ainda, os mapas de "densidade urbana", "de buffer" e o "urbano", conforme já evidenciado. Assim, com a atribuição de pesos e notas, serão elaborados três mapas de perigo à inundação, obtidos por três metodologias distintas (carta topográfica, imagem do ASTER e do SRTM.).

O objetivo do trabalho é o de gerar mapas de perigo à inundação para o município de Jaguari através de três fontes de dados altimétricos. 


\section{Metodologia}

Antes de segmentar os procedimentos metodológicos envolvidos nesse trabalho, há de citar os aplicativos os quais foram utilizados. Assim, para geração dos mapas, foi utilizado o ArcGIS®, versão 10.1, já para realizar o cruzamento dos mapas usou-se o aplicativo Vista Saga, desenvolvido pela UFRJ, disponibilizado gratuitamente no sítio < http:/ / wmw.viconsaga.com.br/lageop/ downloads.php>, e por fim, empregou-se o aplicativo Google Earth como suporte à análise dos dados.

Os procedimentos teórico-práticos serão dispostos cronologicamente a seguir.

Estudos iniciais

Inicialmente foi realizado um prévio estudo de trabalhos já publicados, a fim de tentar explicitar se há algum padrão quanto às bases cartográficas a serem utilizadas para o mapeamento detalhado de áreas de perigo a inundação, bem como, identificar algum possível padrão de atribuição de "pesos" e "notas" aos mapas e suas convenções cartográficas, respectivamente.

É mister diferenciar os conceitos de "peso" e o de "nota" caracterizados nesse trabalho. Peso será o valor atribuído para cada mapa, e o mesmo deverá totalizar o valor de 100. Já nota, será o valor atribuído para cada feição do mapa (convenção), podendo variar de 0 a 10.

Base de dados

Para estruturar as bases metodológicas do presente trabalho, utilizaram-se três fontes de dados em três diferentes escalas:

- Cartas topográficas de Jaguari (folha SH-21-X-D-II-4) e de São Vicente do Sul (folha SH-21-X-D-V-2), ambas na escala 1:50.000;

- Uma cena do sensor SRTM (folha SH-21-X-D), a qual possui resolução espacial de $90 \mathrm{~m}$, disponibilizado gratuitamente no sítio da EMBRAPA: < bttp://www. relevobr.cnpm.embrapa.br/download/>;

- Uma imagem da plataforma ASTER, a qual possui resolução espacial de $30 \mathrm{~m}$, disponibilizado gratuitamente no sítio: <http://earthexplorer.usgs.gov/>.

Destaca-se que o recorte espacial de análise dos dados foi delimitado em função do perímetro urbano de Jaguari, conforme descrito na Lei Municipal número 1836 de outubro de 1989.

Sabe-se que as cartas topográficas na escala 1:50.000 são oriundas de levantamentos aerofotogramétricos realizadas no ano de 1975. As mesmas possuem curvas de nível na equidistância de 20 metros, e encontram-se disponíveis em formato analógico, no Rio Grande do Sul, na Diretoria do Serviço Geográfico do Exército (DSG)

Souza e Matricardi (2013) informam que o MDE do SRTM possui uma resolução espacial de 3 arcos-segundos (90x90 metros), e o mesmo é originado por um radar. A grande vantagem em trabalhar com as imagens do SRTM é o fato das mesmas serem oriundas de radares, logo, as mesmas não possuem interferências significativas da atmosfera. Destaca-se, ainda, que o as imagens SRTM, de 90 metros de resolução espacial, são oriundas da banda "C" do radar.

Souza e Matricardi (2013) explicitam que o MDE do ASTER possui uma resolução espacial de 30 metros, sendo que o ASTER está a bordo do satélite Terra, sendo assim, constituído por imagens orbitais, podendo, inclusive, sofrer interferências climáticas (nuvens).
6 Disponível em: <http:// www.concar.ibge.gov.br/ PaginaForum/Forum_Sul/ Apresentacoes/RIO $\% 20$ GRANDE\% 20 DO $\% 20$ SUL_CONCAR.pdf $>$. Acesso em 23 fev.2014.

Geografia Ensino \& Pesquisa, v. 18, n.2, p. 123-144, maio/ago. 2014

Prina, B. Z.; Trentin, R. 
Mapas de Suscetibilidade - MDEs

Destaca-se que para realizar a modelagem dos MDEs, foi utilizado o algoritmo do "Topo to Raster", do ArcGIS®. No que tange ao planejamento detalhado para a geração dos MDEs, a seguir, destacar-se-ão todos os procedimentos realizados para cada uma das metodologias abordadas.

Alerta-se que para realização dos MDEs, foi utilizada uma área maior que a de análise, a fim de realizar a modelagem e não haver o "efeito de borda".

\section{Carta topográfica}

Utilizaram-se as cartas topográficas de Jaguari e de São Vicente do Sul (escala 1:50.000). As mesmas receberam um tratamento dos dados no aplicativo ArcGIS ${ }^{\circledR}$. Assim, para geração do MDE digitalizaram-se as curvas de nível das cartas e os pontos cotados, e uniram-se a essas as informações da rede de drenagem do local. Por fim, com o algoritmo do "Topo to Raster", criou-se o MDE. Assim, para a referida área, totalizaram-se 10 curvas de nível, variando de $100 \mathrm{~m}$ a $300 \mathrm{~m}$ de altitude, e um ponto cotado, no valor de $307 \mathrm{~m}$, resultando em uma amplitude de $207 \mathrm{~m}$.

Recorte em função do perímetro urbano da cidade, georreferenciamento e conversão da projeção cartográfica para o sistema de referência SIRGAS 2000.

Recorte em função do perímetro urbano da cidade e conversão da projeção cartográfica para o sistema de referência SIRGAS 2000.
Geografia Ensino \& Pesquisa, v. 18, n.2, p. 123-144, maio/ago. 2014.

Uso de três fontes de dados altimétricos para identificação de áreas com perigos à inundação
SRTM

Para geração do mapa de suscetibilidade com a utilização da imagem SRTM, houve um prévio tratamento dos dados, no ambiente do ArcGIS ${ }^{8}{ }^{8}$. Após isso, utilizou-se a ferramenta "Raster to Point", do mesmo aplicativo, a fim de converter a informação matricial para feições pontuais da altimetria do local, para realização do MDE. Assim, para a referida área, totalizaram-se 1484 pontos, com informações altimétricas sintetizadas entre as cotas de $95 \mathrm{~m}$ e $276 \mathrm{~m}$ de altitude, com uma amplitude de $181 \mathrm{~m}$.

\section{ASTER}

Para geração do MDE do ASTER, houve os mesmos procedimentos adotados com a imagem SRTM. Porém, a referida área, englobou 9931 pontos, com informações altimétricas sintetizadas entre as cotas de $80 \mathrm{~m}$ e $288 \mathrm{~m}$ de altitude, com uma amplitude de $208 \mathrm{~m}$.

\section{Atribuição das notas à altitude}

Para realizar a atribuição das notas, utilizou-se o conceito estatístico do "quartil". Destaca-se que com o uso do quartil o conjunto ordenado dos valores altimétricos ficou subdividido em partes iguais (GUIMARÃES, 2007). Assim sendo, os dados foram subdivididos em 10 classes, conforme descrito na Figura 2.

A atribuição dos pesos para as 10 classes ocorreu de forma ordinária, sendo que a classe altimétrica de menor cota recebeu a maior nota (10), e assim por diante, conforme descrito na Figura 3.

\section{Atribuição das notas à altitude}

Entre os pesos atribuídos aos mapas, o de suscetibilidade será aquele que possuirá o maior valor, visto que, a altimetria do terreno é um fator natural às áreas inundáveis, ou seja, planícies localizadas na várzea são áreas com maior probabilidade de ocorrer inundações (JUNK, 1997 apud COLOMBO, s.d.). Destarte, atribui-se o peso de 35 (do total de 100) para o mapa de suscetibilidade (o MDE). 
Figura 2 - Subdivisão final das classes de altitude: do ASTER (a), do SRTM (b) e da carta topográfica (c).

MDE - ASTER
Classes de altitude:
$80,11-93,92$
$\mathbf{\square}, 92-97,98$
$97,98-101,23$
$\square 101,23-105,29$
$\square 105,29-110,16$
$\mathbf{\square} 110,16-116,66$
$\mathbf{\square} 116,66-128,85$
$\mathbf{\square} 128,85-148,34$
$148,34-188,14$
$\mathbf{\square} 188,14-287,23$

(a)

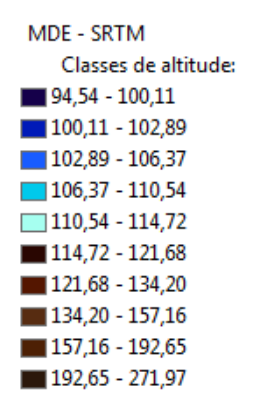

(b)

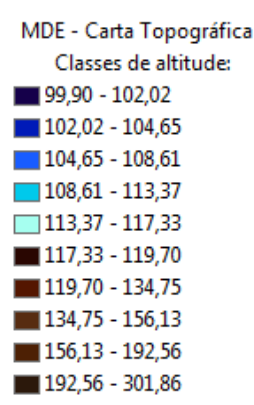

(c)

Fonte: organizado pelos autores.

Figura 3 - Subdivisão final das classes de altitude: do ASTER (a), do SRTM (b) e da carta topográfica (c).

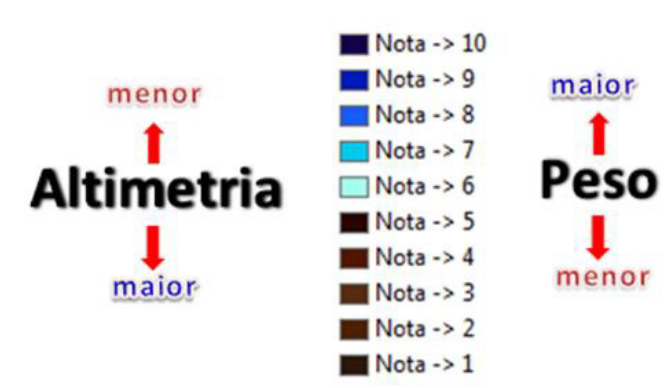

Fonte: organizado pelos autores.

Mapas de declividade

Alerta-se que para realização dos MDEs, foi utilizada uma área maior que a de análise, a fim de realizar a modelagem e não haver o "efeito de borda".

Geração dos mapas

Para geração dos mapas de declividade, utilizaram-se os MDEs originados anteriormente. Para tal procedimento, usou-se a ferramenta "Slope", do aplicativo ArcGIS ${ }^{\circledR}$. Assim sendo, a metodologia de criação dos mapas de declividade foi similar a todas as três bases cartográficas (originado do SRTM, ASTER e carta topográfica), com a única diferença de que foram utilizados os seus respectivos MDEs.

Assim, para determinar os referidos mapas, utilizou-se o padrão de declividade do Instituto de Pesquisas Tecnológicas do estado de São Paulo (IPT, 1981), o qual possui a declividade segmentada em 4 classes, conforme descrito no Quadro 1.

\section{Atribuição das notas à declividade}

Conforme já mencionado na altimetria, a declividade é outro fator de extrema importância para estudos que envolvem áreas inundáveis, visto o fator natural das inundações ocuparem, principalmente, as áreas planas. Assim sendo, as menores declividades receberão as maiores notas.

Para sintetizar a análise da atribuição das notas a essa classe, tem-se a Figura 4, a qual exemplifica de forma visual a referida caracterização.

Intensifica-se que o planejamento das notas referente a declividade foi baseada no trabalho de Magalhães et al (2011), porém o mesmo baseou-se no intervalo de declividades sugerido pela EMBRAPA.

Geografia Ensino \& Pesquisa, v. 18, n.2, p. 123-144, maio/ago. 2014

Prina, B. Z.; Trentin, R. 
Quadro 1 - Descrição das classes de declividades, juntamente com seus respectivos intervalos.

\begin{tabular}{|c|l|l|}
\hline Classes & \multicolumn{3}{|c|}{ Descrição } \\
\hline$<2 \%$ & $\begin{array}{l}\text { Áreas muito planas, e quando estão localizadas próximas as redes de } \\
\text { drenagem ficam sujeitas a inundação (TRENTIN e ROBAINA, 2005). }\end{array}$ \\
\hline $2-5 \%$ & $\begin{array}{l}\text { Áreas planas, características de processos de deposição de sedimentos } \\
\text { (TRENTIN e ROBAINA, 2005). }\end{array}$ \\
\hline $5-15 \%$ & $\begin{array}{l}\text { Áreas onduladas com processos de dinâmica superficiais erosivos moderados a } \\
\text { acentuado (TRENTIN e ROBAINA, 2005). }\end{array}$ \\
\hline$>15 \%$ & $\begin{array}{l}\text { Declividade com áreas propícias à ocorrência de escorregamentos e } \\
\text { movimentos de massa (TRENTIN e ROBAINA, 2005). }\end{array}$ \\
\hline
\end{tabular}

Fonte: organizado pelos autores.

Figura 4-Exemplificação das notas atribuídas à declividade.

\begin{tabular}{|c|c|c|c|}
\hline menor & \multicolumn{2}{|l|}{ Classes: } & maior \\
\hline & $<2 \%$ & - Nota 10 & \\
\hline & $\square 2-5 \%$ & - Nota 7 & \\
\hline & $\square 5-15 \%$ & - Nota 5 & \\
\hline maior & $>15 \%$ & - Nota 1 & menor \\
\hline
\end{tabular}

Fonte: organizado pelos autores.

\section{Atribuição das notas à declividade}

Oliveira e Guasselli (2011) mencionam que "um dos principais parâmetros influenciadores das inundações, inserido no mapeamento geomorfológico, é a declividade, pois permite estipular a velocidade de escoamento das águas". Há de se destacar que a declividades entre 0 e $5 \%$ são as que possuem maior influência em áreas inundáveis, pelo fato de representar as várzeas e os terraços fluviais (DIAS et al., 2004 apud OLIVEIRA e GUASSELLI, 2011).

9 Novo Código Florestal Sistema FAEP. Página 62.
Geografia Ensino \& Pesquisa, v. 18, n.2, p. 123-144, maio/ago. 2014.

Uso de três fontes de dados altimétricos para identificação de áreas com perigos à inundação

Ainda, conforme já justificado, o fator natural, envolve um processo que retoma ao mapa de declividade a atribuição de uma grande contribuição no acontecimento de uma inundação, assim, o segundo maior peso será inserido a esse mapa, com o valor de 25.

Mapa de buffer

Para geração do mapa de buffer utilizou-se a base hidrográfica digitalizada do perímetro urbano do município de Jaguari e a partir desse, implantaram-se distintos buffers. Como padrão nos offsets utilizou-se a Lei 12.651 (Novo Código Florestal) como referência, considerando, assim, cinco buffers: $30 \mathrm{~m}, 50 \mathrm{~m}, 100 \mathrm{~m}, 200 \mathrm{~m}$, e $500 \mathrm{~m}^{9}$. Sabe-se que a referida lei, impõe cada um desses buffers a respectiva largura do rio. Nesse trabalho, utilizar-se-ão todos os buffers a fim de mapear com distintas áreas de abrangência a localização ou não de áreas com maior ou menor grau de perigo, sendo um dos critérios à análise final.

\section{Atribuição das notas à declividade}

Conforme a descrição de Trentin e Robaina (2005) são sujeitas a inundação as "áreas muito planas, e quando estão localizadas próximas as redes de drenagem [...]”. Assim sendo, criou-se o mapa de buffer a fim de contribuir na identificação dos locais com maiores perigos (Figura 5). 
Figura 5-Exemplificação das notas atribuídas ao mapa de buffer.

\begin{tabular}{|c|c|c|}
\hline \multirow{2}{*}{ menor } & Valor do Buffer & Notas \\
\hline & $30 \mathrm{~m}$ & 10 \\
\hline \multirow{3}{*}{ Buffer } & $50 \mathrm{~m}$ & 9 \\
\hline & $100 \mathrm{~m}$ & 6 \\
\hline & $200 \mathrm{~m}$ & 3 \\
\hline maior & $500 m$ & 1 \\
\hline
\end{tabular}

Fonte: organizado pelos autores.

\section{Atribuição do peso ao mapa de buffer}

Após um estudo exaustivo quanto às variáveis que influenciariam no mapeamento das áreas com maiores perigos, entendeu-se que, nem sempre utilizando as áreas mais baixas (altimetria) e planas (declividade) o perigo estaria melhor ou pior apontado. Assim sendo, caracterizou-se, o mapa de buffer, como uma informação importante, porém não principal, com isso, o peso atribuído à referida variável foi de 10 .

Mapa urbano

Para realizar a construção do mapa urbano, vetorizaram-se todas as construções (casas, lojas, galpões, etc.) do perímetro urbano do município ${ }^{10}$, bem como realizou o mapeamento dos bairros do município. Destaca-se que para construir a base cartográfica dos bairros, utilizou-se das leis municipais ${ }^{11}$ que descreviam a localização e limites destes, assim sendo, a mensuração dos mesmos, foi realizada por meio da interpretação dessa documentação.

\section{Atribuição das notas ao mapa urbano}

Conforme já mencionado e destacado, o mapa urbano ficou segmentado em duas classes, as construções e a mancha urbana (delimitação dos bairros). Sendo que as construções receberam uma nota de 10 e a mancha urbana, nota 7.

\section{Atribuição das notas ao mapa urbano}

Outra variável de extrema importância, e que ocupou o terceiro maior peso, foi o mapa urbano, visto que o mesmo está sendo utilizado para a geração final de um mapa de perigo. Conforme menciona Cutter e Press (2001) o perigo está descrito como o "indício de ameaça às pessoas, bem como de seus objetos", assim sendo o mapeamento das construções faz-se de extrema importância, a fim de identificar onde estão as áreas de concentração populacional, para posteriormente estimar o perigo (ou não) desses locais quanto às inundações. Assim, o mapa urbano possuirá o peso de 20, o terceiro maior.

Mapa de densidade urbana

Valerio Filho e Belisário (2012) destacam que o crescimento urbano aumenta a impermeabilização do solo, comprometendo a capacidade de suporte da drenagem quando há um maior escoamento superficial, gerando, assim, uma maior probabilidade de ocorrências de inundações à jusante da bacia hidrográfica. Após isso, verificou-se que a análise do

Geografia Ensino \& Pesquisa, v. 18, n.2, p. 123-144, maio/ago. 2014

Prina, B. Z.; Trentin, $\mathbf{R}$

ISSN 2236-4994 131 
adensamento urbano é um fator inerente ao mapeamento do perigo às inundações. Assim, para realizar o referido mapeamento, utilizou-se a ferramenta Kernel Density do ArcGIS ${ }^{\circledR}$, e dividiu-se o resultado em quatro classes, segmentadas pelo conceito estatístico do quartil. Analisa-se que a densidade em questão está relacionada ao número de construções/hectare.

\section{Atribuição das notas à densidade urbana}

Após a construção do mapa com as quatro classes, informaram-se as notas conforme o Figura 6. Assim, fica visível que quanto maior a densidade, maior foi o peso da variável.

Figura 6 - Exemplificação das notas atribuídas às classes de densidade urbana.

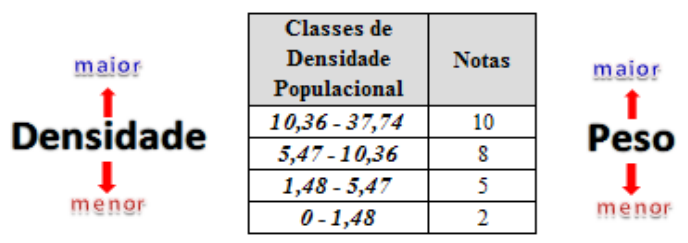

Fonte: organizado pelos autores.

\section{Atribuição do peso à densidade urbana}

Conforme já destacado, constatou-se muito importante haver um mapa com informações de densidade urbana, assim o mesmo mostrar-se-á importante no cruzamento das informações, conforme já justificado, assim, o mesmo receberá o peso de 10.

Síntese das atribuições das notas e dos pesos finais

Conforme já distinguido, os pesos são os valores referenciados aos mapas (valor que deverá totalizar 100), e notas são informações entrelaçadas às convenções desses (as classes). Assim, sendo, as Figuras 7 e 8, resumem as informações quanto aos pesos utilizados. Já a Figura 9 sintetiza as informações das notas.

Figura 7 - Resumo dos pesos utilizados.

Geografia Ensino \& Pesquisa, v. 18, n.2, p. 123-144, maio/ago. 2014.

Uso de três fontes de dados altimétricos para identificação de áreas com perigos à inundação

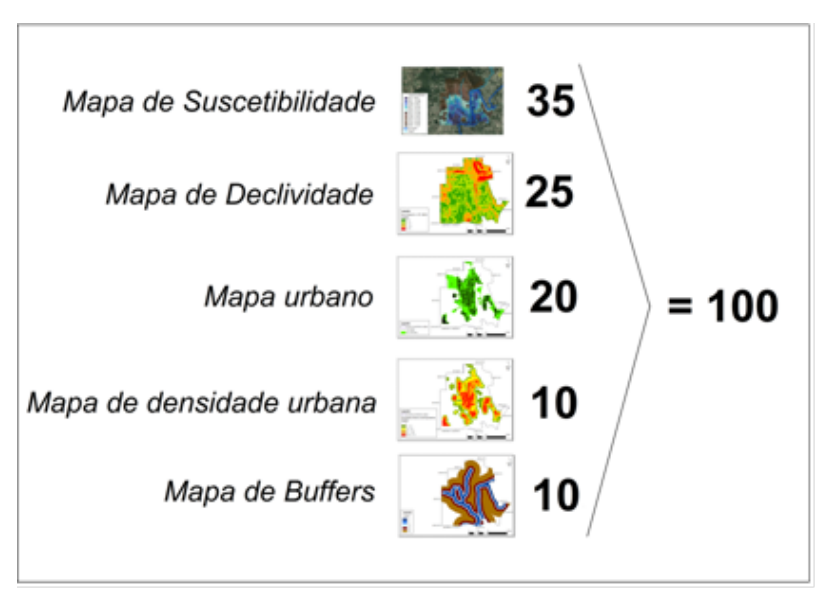

Fonte: organizado pelos autores 
Figura 8 - Ilustração dos pesos utilizados.

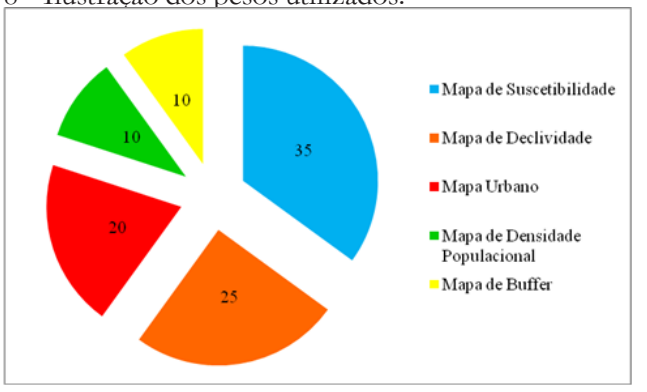

Fonte: organizado pelos autores

Figura 9 - Ilustração dos pesos utilizados.

\begin{tabular}{|c|c|c|c|}
\hline \multicolumn{2}{|c|}{ MDE (35) } & \multicolumn{2}{|c|}{ Declividade (25) } \\
\hline Classes & Notas & Classes & Notas \\
\hline $1^{a}$ classe & 10 & $<2 \%$ & 10 \\
\hline $2^{a}$ classe & 9 & $2-5 \%$ & 7 \\
\hline $3^{a}$ classe & 8 & $5-15 \%$ & 5 \\
\hline $4^{a}$ classe & 7 & $>15 \%$ & 1 \\
\hline $5^{a}$ classe & 6 & & \\
\hline $6^{a}$ classe & 5 & & \\
\hline $7^{a}$ classe & 4 & & \\
\hline $8^{a}$ classe & 3 & & \\
\hline $9^{a}$ classe & 2 & & \\
\hline $10^{a}$ classe & 1 & & \\
\hline
\end{tabular}

\begin{tabular}{|c|c|c|c|c|c|}
\hline \multicolumn{2}{|c|}{ Mapa urbano (20) } & \multicolumn{2}{|c|}{ Densidade (10) } & \multicolumn{2}{|c|}{ Buffer (10) } \\
\hline Classes & Notas & Classes & Notas & Classes & Notas \\
\hline Construções & 10 & $0-1,48$ & 2 & $30 \mathrm{~m}$ & 10 \\
\hline Mancha urbana & 7 & $1,48-5,47$ & 5 & $50 \mathrm{~m}$ & 9 \\
\hline & & $5,47-10,36$ & 8 & $100 \mathrm{~m}$ & 6 \\
\hline & & $10,36-37,74$ & 10 & $200 \mathrm{~m}$ & 3 \\
\hline & & & & $500 \mathrm{~m}$ & 1 \\
\hline
\end{tabular}

Fonte: organizado pelos autores.

Cruzamento das informações e análise dos dados

Como etapa de geração do resultado final, utilizando o aplicativo Vista Saga, cruzaram-se todos os planos de informações, com suas respectivas notas e pesos, resultando, posteriormente, em três mapas de perigo à inundação, originados dos dados das cartas topográficas, e das imagens SRTM e ASTER. Posteriormente, com o aplicativo ArcGIS ${ }^{\circledR}$, importaram-se os resultados adquiridos no aplicativo Vista Saga, para a realização de uma análise visual com a ajuda do Google Earth.

\section{Discussão dos resultados}

Resultado dos mapas de Suscetibilidade

Conforme os pesos atribuídos, o mapa de suscetibilidade é aquele que sintetizou o maior valor, logo, a partir dele, foi gerado o mapa de declividade, assim sendo, o resultado adquirido nessa etapa faz-se de extrema importância para a análise final (mapa de perigo). O resultado do MDE com o uso da carta topográfica, do SRTM e do ASTER estão explicitados na Figura 10.

Após a análise de todos os MDEs verificou-se que os dados oriundos das cartas topográficas foram os que apresentaram as maiores discrepâncias para com a verdade terrestre. Tal registro é ratificado na parte mais ao sul da imagem, onde pode ser constatada a existência de uma grande várzea às margens do rio. A referida análise é destacada no fato em que a carta topográfica não possui nenhuma informação altimétrica (sem curvas de nível) no referido local (Figura 11), logo, houve uma defasagem no MDE gerado, e, por consequência das informações oriundas dessa.

Geografia Ensino \& Pesquisa, v. 18, n.2, p. 123-144, maio/ago. 2014

Prina, B. Z.; Trentin, R.

ISSN 2236-4994 133 
Figura 10 - MDE resultante com o uso da carta topográfica (a), SRTM (b) e ASTER (c).

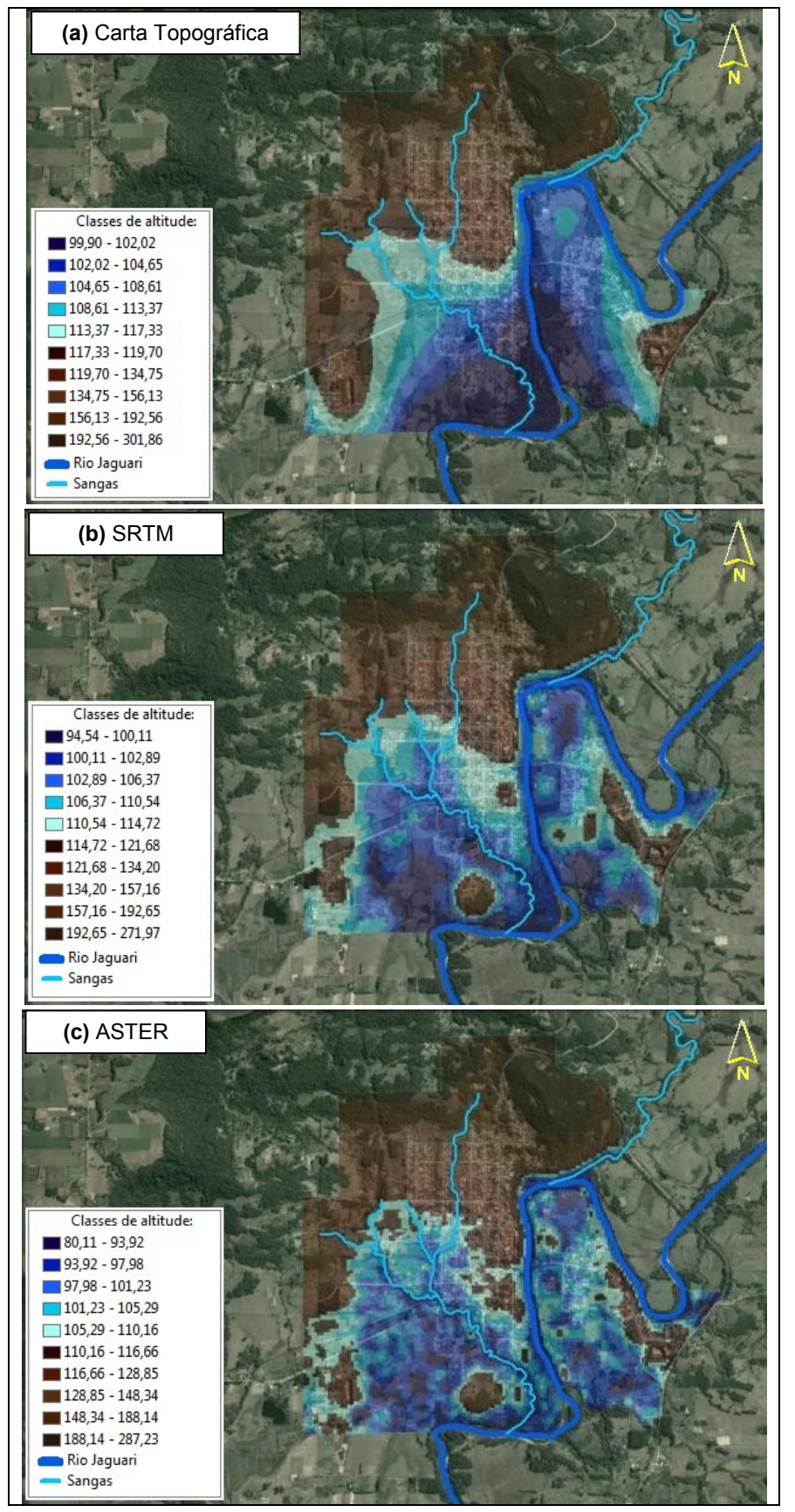

Fonte: organizado pelos autores.

Figura 11 - Retângulo vermelho: local com a ausência de informações altimétricas.

Geografia Ensino \& Pesquisa, v. 18, n.2, p. 123-144, maio/ago. 2014.

Uso de três fontes de dados altimétricos para identificação de áreas com perigos à inundação

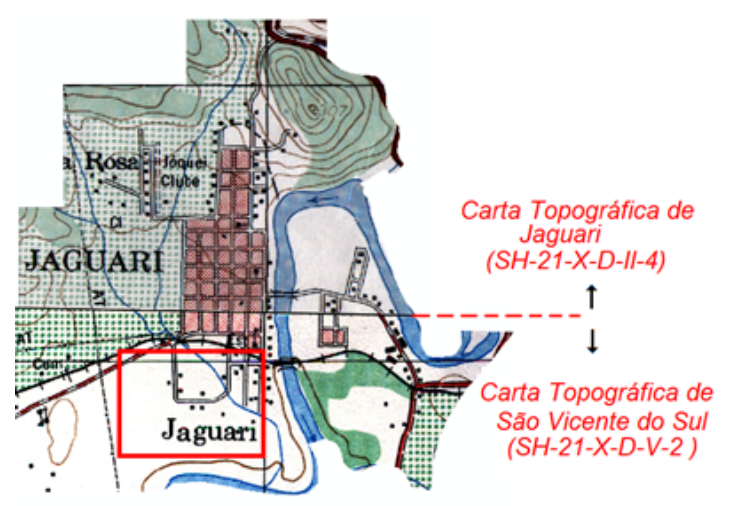

Fonte: organizado pelos autores. 
Resultado dos mapas de Suscetibilidade

Conforme as bases de dados altimétricos (MDEs) destacados anteriormente, geraram-se os mapas de declividades, os quais estão destacados na Figura 12 (a) das cartas topográficas, 12 (b) do SRTM e 12 (c) do ASTER.

Outra análise a ser retratada, é na comparação entre a declividade do ASTER para com a do SRTM. Visto que a primeira classe de declividade é bem pequena $(<2 \%)$, logo abrange apenas os locais realmente planos, verifica-se que os dados oriundos do ASTER possuíram um efeito "sal-pimenta", ou seja, uma imagem com aspecto granuloso. Tal informação pode ser destacada visto que o ASTER possui informações altimétricas espaçadas numa grade de 30x30m. Já o SRTM, que possui a grade de informações de 90x90m, apresenta um aspecto mais uniforme da declividade, concentrando, além de tudo, um maior percentual de áreas planas $(<2 \%)$ que o ASTER. Tal afirmação é referenciada pelo aspecto visual da imagem, não sendo necessária uma quantificação numérica, pois é insofismável a diferença.

Figura 12 - Mapa de declividade oriundos da carta topográfica (a), SRTM (b) e ASTER (c).
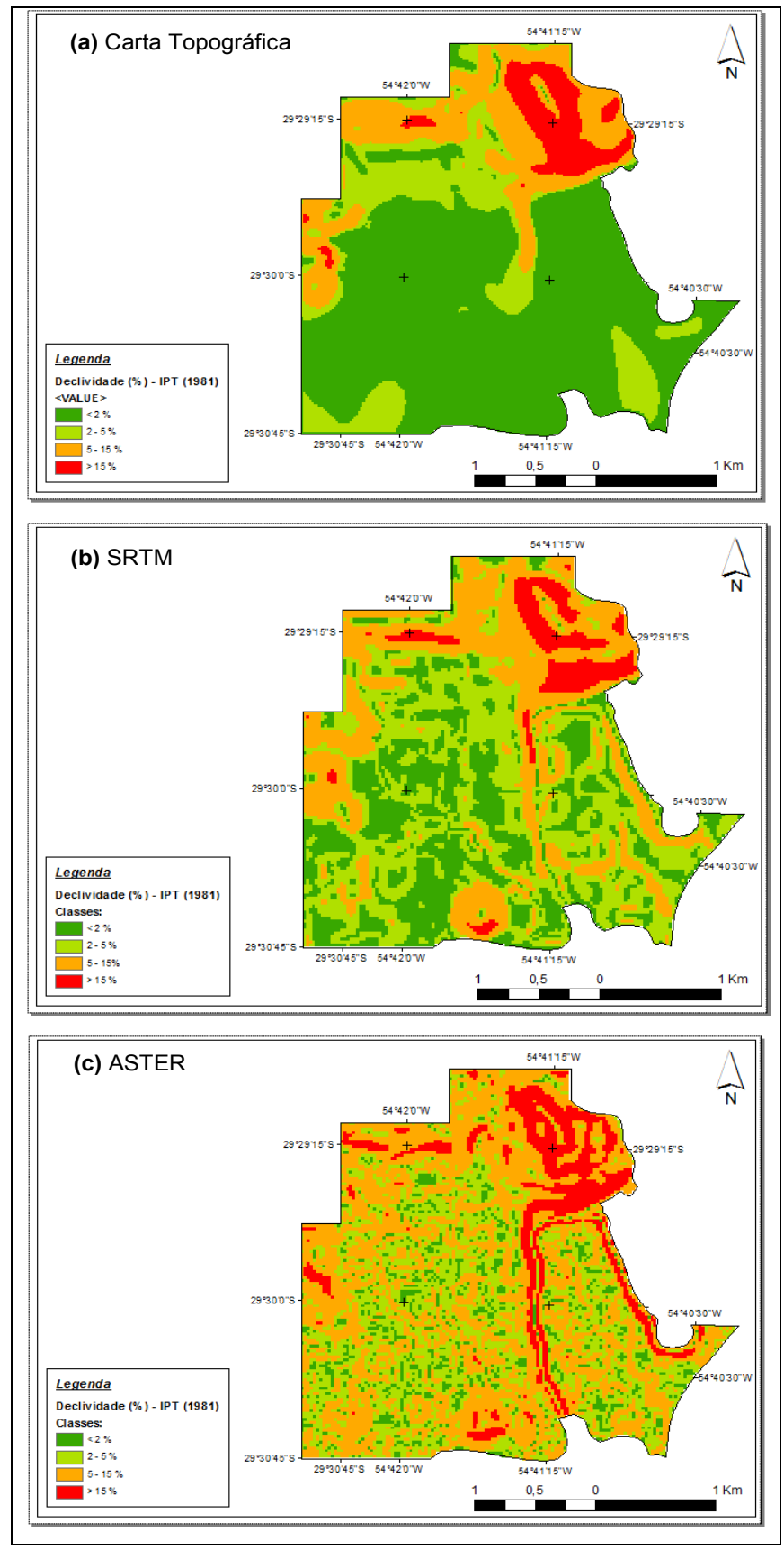

Geografia Ensino \& Pesquisa, v. 18, n.2, p. 123-144, maio/ago. 2014 
Resultado do mapa de buffer e urbano

O resultado da aplicação dos offsets nas áreas ao redor dos trechos hidrográficos está representado na Figura 13. Assim, foram utilizados os buffers de 30, 50, 100, 200 e 500 metros em relação aos corpos hídricos localizados no município.

Enfatiza-se, também, que após o intensivo mapeamento das construções que havia no município de Jaguari, por meio da digitalização manual, pode-se quantificar o número aproximado de residências da área urbana, que totalizou 2418 construções (Figura 14).

Figura 13 - Mapa dos buffers de 30, 50, 100, 200 e 500 metros em relação aos corpos hídricos localizados no município.

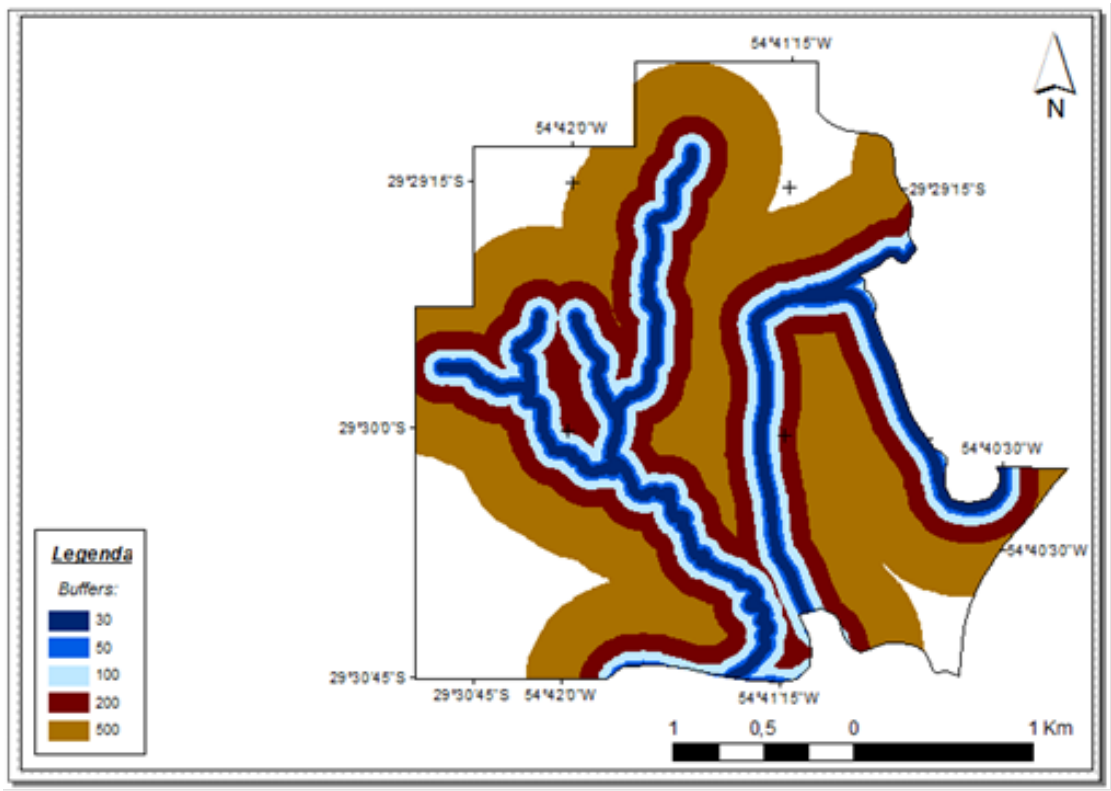

Fonte: organizado pelos autores.

Figura 14-Mapa urbano resultante após o processo de digitalização, exemplificando a disponibilização espacial das construções no município.

Geografia Ensino \& Pesquisa, v. 18, n.2, p. 123-144, maio/ago. 2014

Uso de três fontes de dados altimétricos para identificação de áreas com perigos à inundação

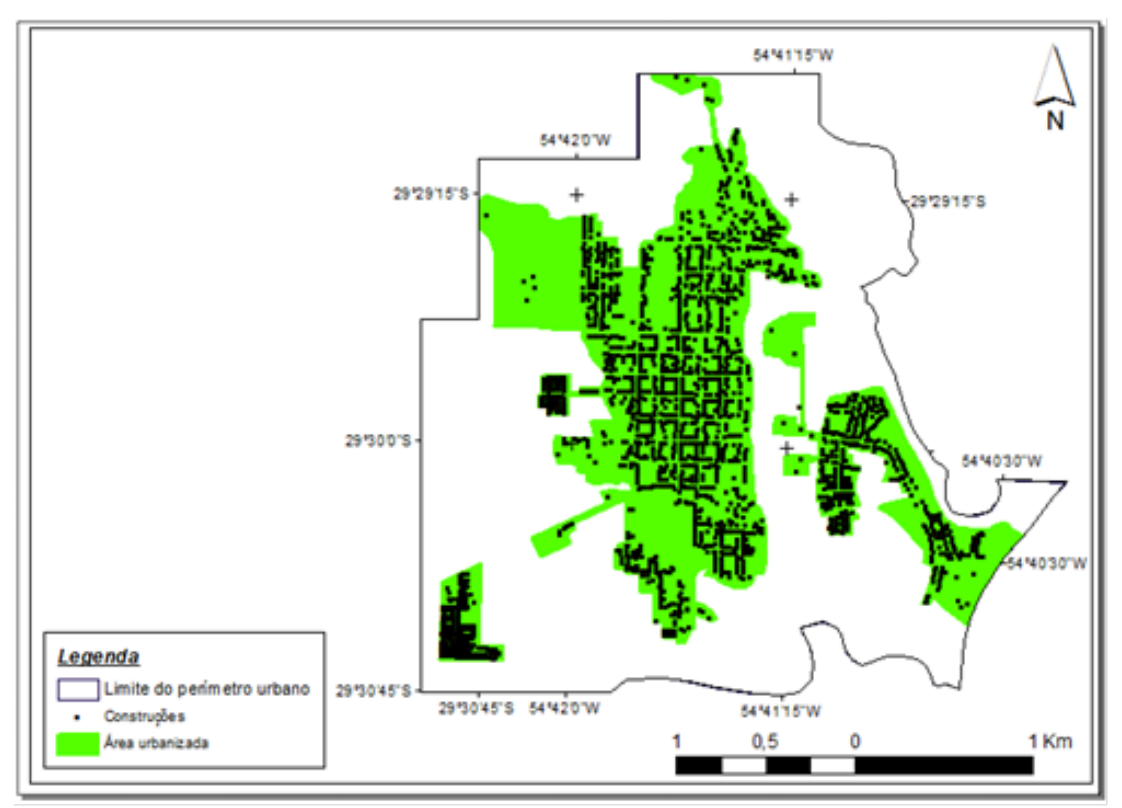

Fonte: organizado pelos autores. 
Resultado do mapa de buffer e urbano

Com o uso da ferramenta Kernel Density (do ArcGIS®), houve a geração do mapa de densidade urbana, o qual foi segmentado em quatro classes, subdivididas a partir da aplicação do uso do quartil. O referido mapa (Figura 15) mostra-se de grande importância, pois, dessa forma, identificaram-se as áreas com a maior densidade de construções (população). $\mathrm{Na}$ análise visual da imagem fica visível que há uma uniformidade quanto a concentração da população, com agrupamentos urbanos em centros específicos.

Figura 15 - Resultado no mapeamento da densidade urbana após a utilização da ferramenta Kernel Density do ArcGIS®.

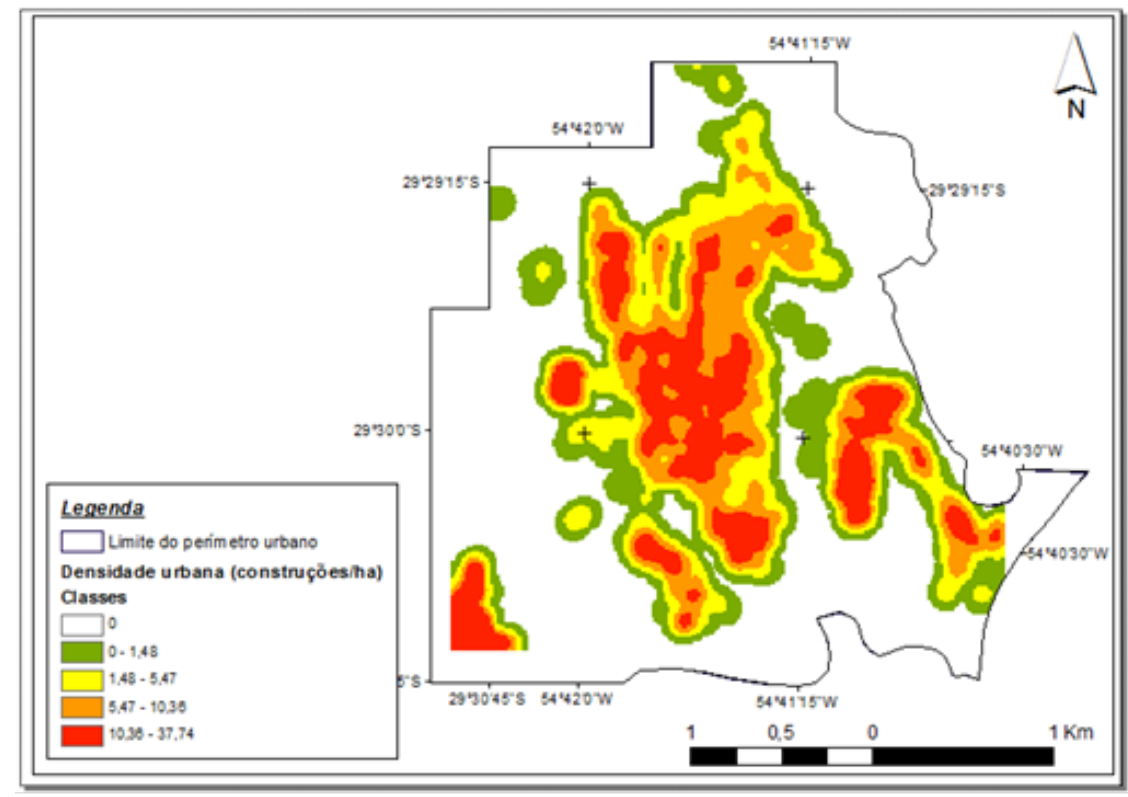

Fonte: organizado pelos autores.

Resultado do Cruzamento das informações: mapa de perigo

A partir do mapeamento dos distintos mapas e da atribuição dos pesos e das notas, por meio do aplicativo Vista Saga geraram-se os mapas de perigo à inundação do perímetro urbano do município de Jaguari. Deve-se destacar, que a partir dos referidos materiais, haverá um pleno planejamento para realização de um levantamento planialtimétrico e cadastral das feições topográficas e terrestres da área de maior probabilidade de ocorrência de inundações. Assim sendo, as Figuras 16 (origem da carta topográfica), 17 (origem do sensor SRTM) e 18 (origem do ASTER) destacam os mapas de perigo à inundação e a Tabela 1 a quantificação, em hectares, da área da região de alto perigo a inundação.

Tabela 1 - Quantificação das áreas de alto perigo à inundação no município de Jaguari nas três bases de dados utilizados.

\begin{tabular}{c|c|c|c}
\hline & $\begin{array}{c}\text { Carta } \\
\text { Topográfica }\end{array}$ & SRTM & ASTER \\
\hline Área (ha) & 82,41 & 37,39 & 20,39 \\
\hline
\end{tabular}

Geografia Ensino \& Pesquisa, v. 18, n.2, p. 123-144, maio/ago. 2014

Prina, B. Z.; Trentin, R. 
Figura 16 - Mapa de perigo à inundação com uso da carta topográfica: (a) área geral, (b) área detalhada do alto perigo. Visualização no Google Earth.

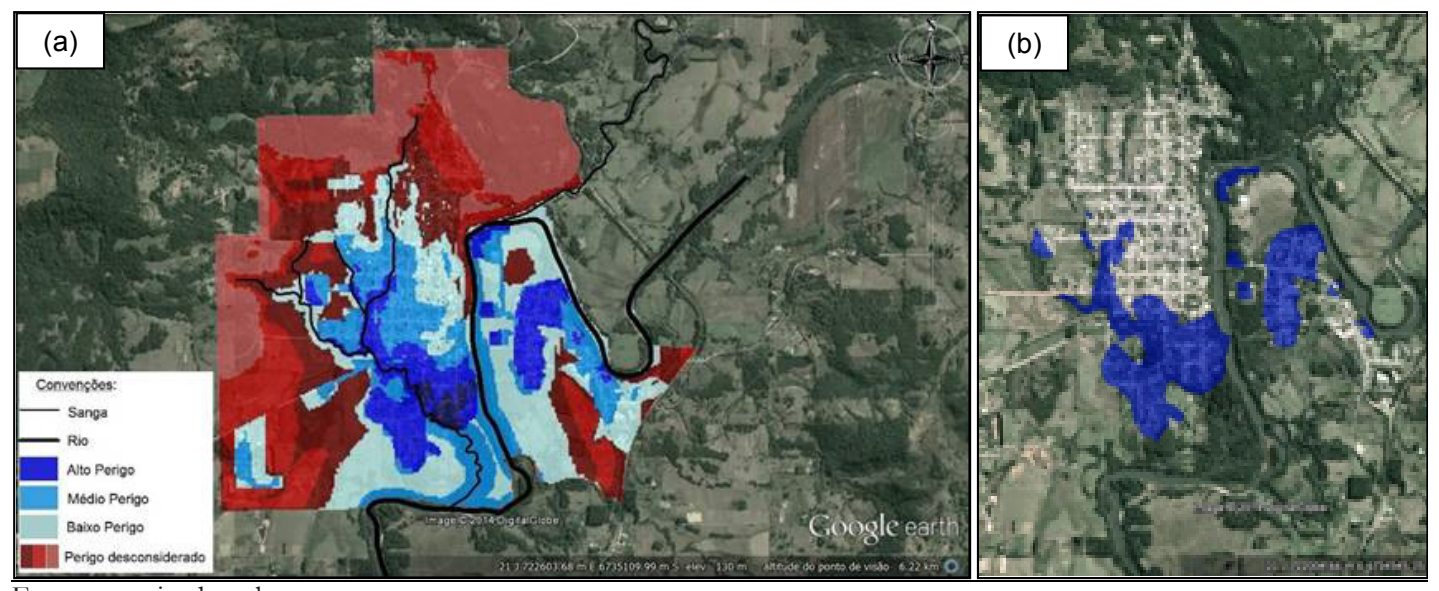

Fonte: organizado pelos autores.

Figura 17 - Mapa de perigo à inundação com uso do MDE do SRTM: (a) área geral, (b) área detalhada do alto perigo. Visualização no Google Earth.
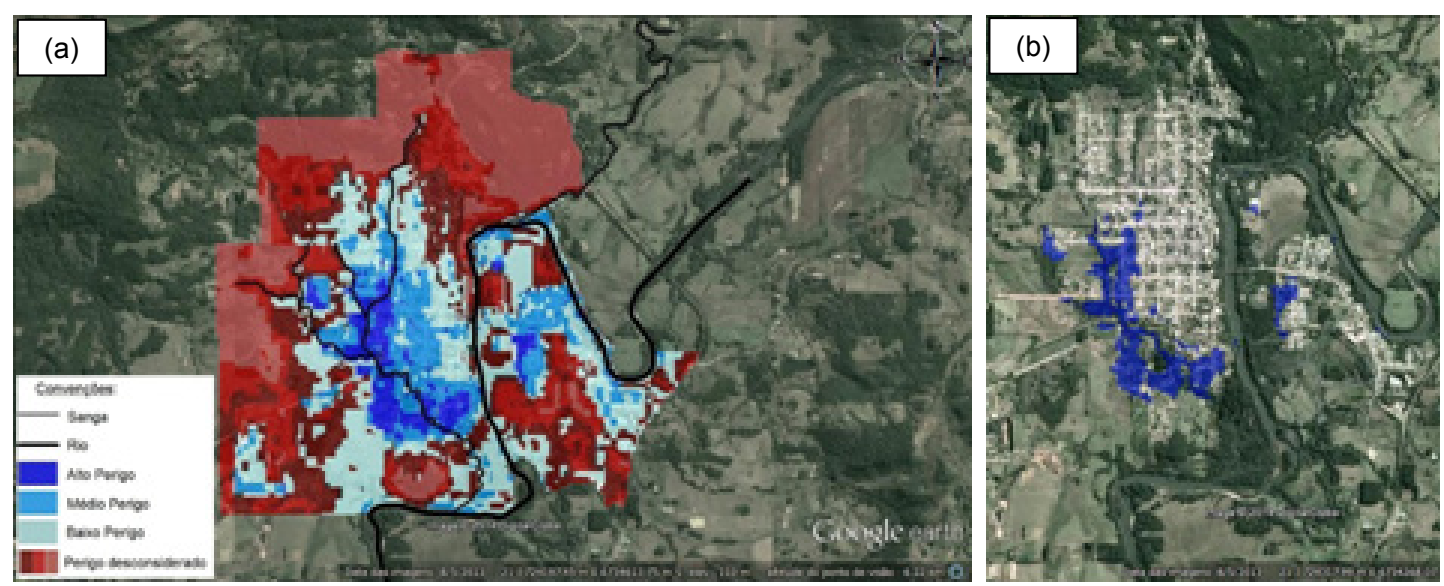

Fonte: organizado pelos autores.

Figura 18 - Mapa de perigo à inundação com uso do MDE do ASTER: (a) área geral, (b) área detalhada do alto perigo. Visualização no Google Earth.

Geografia Ensino \& Pesquisa, v. 18, n.2, p. 123-144, maio/ago. 2014

Uso de três fontes de dados altimétricos para identificação de áreas com perigos à inundação

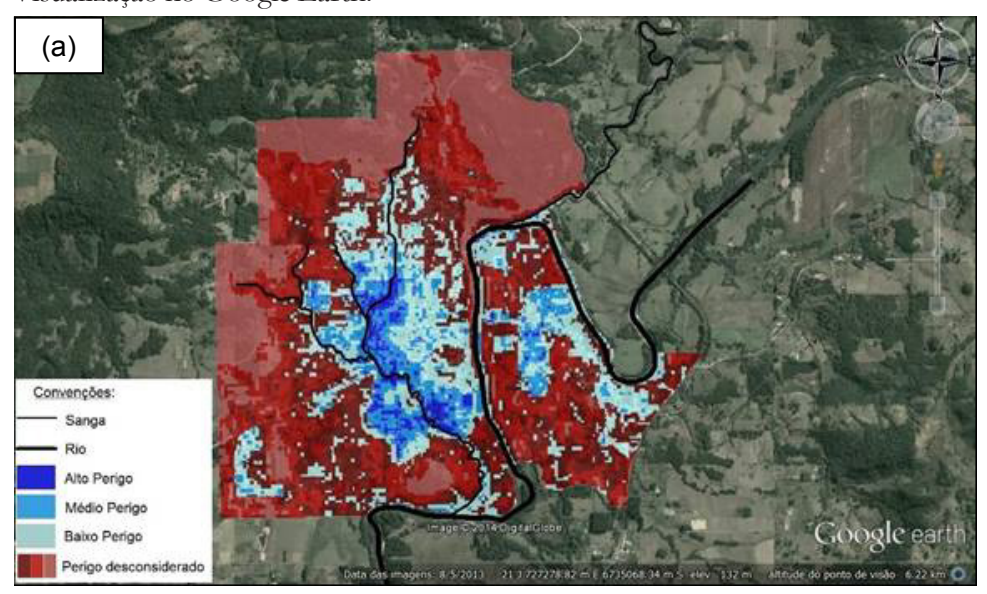

Fonte: organizado pelos autores.

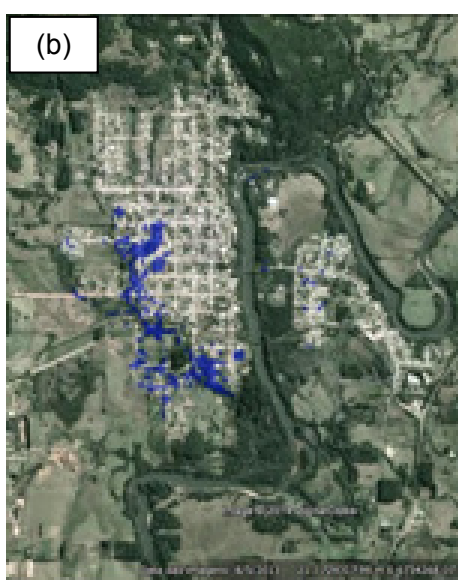


Conforme já destacado, com o uso da carta topográfica, a qual está deficiente de informações altimétricas (Figura 11), foi mensurado uma área bem superior referente ao perigo das outras duas bases de dados.

A fim de mensurar as áreas por bairro, gerou-se a Tabela 2 e 3, a qual identifica de forma minuciosa o perigo à inundação no município.

Para analisar quais das informações possuem as maiores veracidades dos dados, aplicou-se o Coeficiente de Correlação Linear de Pearson $\left(\mathrm{R}^{2}\right)$, o qual exemplifica a intensidade de associação linear existente entre duas variáveis (SOUSA, s.d.). Assim, na análise do perigo quantificado por bairro, registrou-se 93,1\% (Figura 19) de correlação entre os dados do SRTM e do ASTER, 67,1\% entre a carta topográfica e o SRTM e 54,8\% entre a carta e o ASTER.

Figura 19-Maior correlação encontrada: 93,1\%, entre SRTM e ASTER.

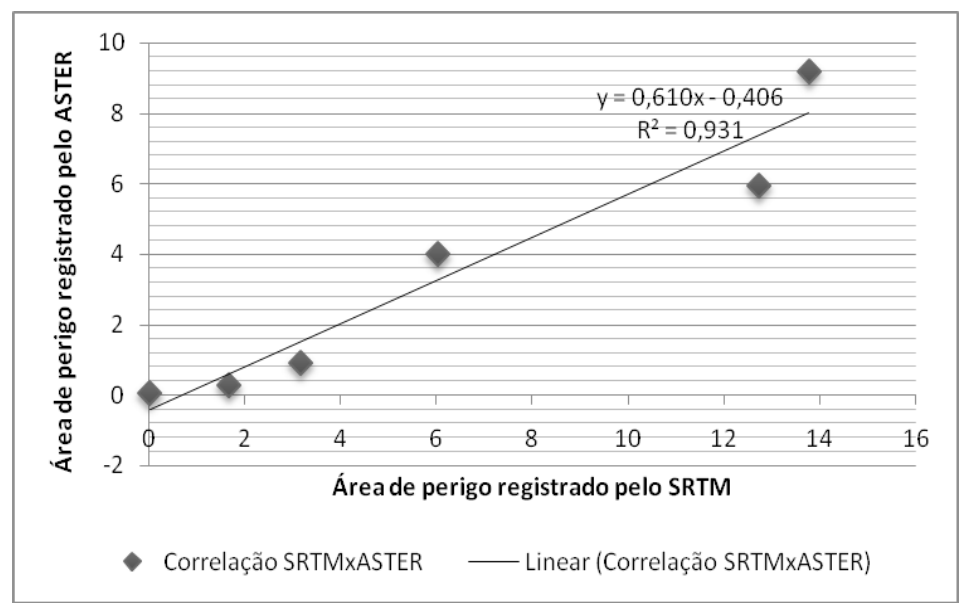

Fonte: organizado pelos autores

Tabela 2 - Quantificação do alto perigo à inundação por bairro.

\begin{tabular}{lcccc}
\hline $\begin{array}{l}\text { Bairros com alto } \\
\text { perigo de inundação: }\end{array}$ & $\begin{array}{c}\text { Base de } \\
\text { dados: } \\
\text { Carta }\end{array}$ & $\begin{array}{c}\text { Base de } \\
\text { dados: } \\
\text { SRTM }\end{array}$ & $\begin{array}{c}\text { Base de } \\
\text { dados: } \\
\text { ASTER }\end{array}$ & $\begin{array}{c}\text { Área do } \\
\text { bairro } \\
\text { (ha) }\end{array}$ \\
\hline Centro & 17,56 & 13,76 & 9,17 & 130,29 \\
\hline Mauá & 13,58 & 6,03 & 4,00 & 13,60 \\
\hline Nossa Senhora Aparecida & 1,72 & 0,02 & 0,06 & 1,77 \\
\hline Promorar & 1,43 & 1,67 & 0,29 & 4,06 \\
\hline Rivera & 23,66 & 3,17 & 0,90 & 57,82 \\
\hline Sagrado Coração de Jesus & $\mathbf{2 4 , 4 6}$ & 12,74 & 5,95 & 31,42 \\
\hline Total & $\mathbf{8 2 , 4 1}$ & $\mathbf{3 7 , 3 9}$ & $\mathbf{2 0 , 3 9}$ & - \\
\hline
\end{tabular}

Fonte: organizado pelos autores

Tabela 3 - Quantificação do alto perigo à inundação por bairro - análise da porcentagem englobada pela área do bairro.

\begin{tabular}{lccc} 
Bairros: & $\begin{array}{c}\text { Base de } \\
\text { dados: } \\
\text { Carta }\end{array}$ & $\begin{array}{c}\text { Base de } \\
\text { dados: } \\
\text { SRTM }\end{array}$ & $\begin{array}{c}\text { Base de } \\
\text { dados: } \\
\text { ASTER }\end{array}$ \\
\hline Centro & $13 \%$ & $11 \%$ & $7 \%$ \\
\hline Mauá & $100 \%$ & $44 \%$ & $29 \%$ \\
\hline Nossa Senhora Aparecida & $97 \%$ & $1 \%$ & $4 \%$ \\
\hline Promorar & $35 \%$ & $41 \%$ & $7 \%$ \\
\hline Rivera & $41 \%$ & $5 \%$ & $2 \%$ \\
\hline Sagrado Coração de Jesus & $78 \%$ & $41 \%$ & $19 \%$ \\
\hline
\end{tabular}

Fonte: organizado pelos autores

Geografia Ensino \& Pesquisa, v. 18, n.2, p. 123-144, maio/ago. 2014

Prina, B. Z.; Trentin, R. 
Perante a análise das Tabelas 2 e 3, fica claro que os dados não são uniformes, e há comprometimento quanto aos resultados obtidos, principalmente no que tange as informações da carta topográfica para com as demais. Esse fato fica claro, ao proceder da análise individual para cada bairro, sendo que, as maiores discrepâncias são encontradas nos bairros Mauá e Nossa Senhora Aparecida (a visualização dos bairros pode ser analisada na Figura 20).

Individualizando a análise para o bairro Nossa Senhora Aparecida, a modelagem da carta topográfica totalizou toda a área como alto perigo à inundação, já para o mesmo bairro, a modelagem com os dados do SRTM resultou em 1\% da área total e do ASTER 4\%. Esse fato pode estar atrelado à generalização cartográfica da carta topográfica.

Nos bairros Mauá e Sagrado Coração de Jesus as divergências também são significativas, porém, devido a localização espacial desses dados, as incoerências podem estar aliadas à falta de informação altimétrica da carta topográfica, conforme já destacado (Figura 11).

Finaliza-se, a análise dos resultados, com a identificação dos bairros que não possuíram área classificada com "alto perigo" à inundação, sendo eles: Santa Rosa, Nossa Senhora de Lourdes e Consolata.

Figura 20 - Mapeamento dos bairros do município de Jaguari.

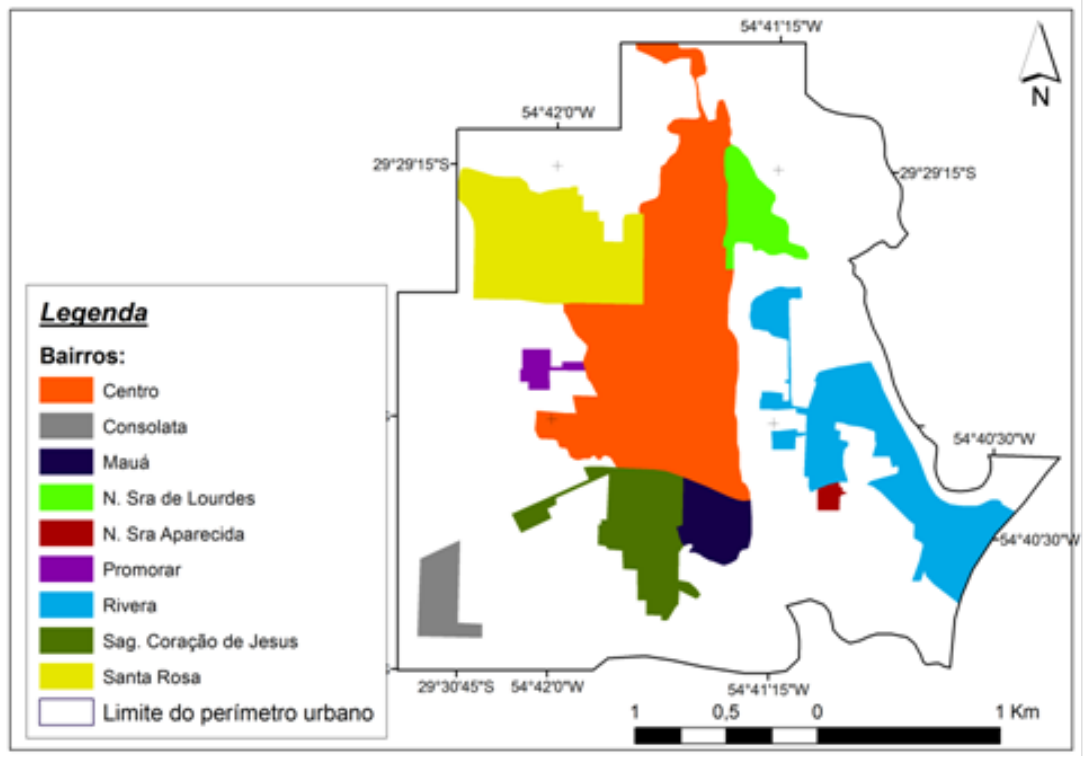

Fonte: organizado pelos autores

\section{Considerações finais}

Geografia Ensino \& Pesquisa, v. 18, n.2, p. 123-144, maio/ago. 2014.

Uso de três fontes de dados altimétricos para identificação de áreas com perigos à inundação
Com esse estudo foram avaliadas três fontes de dados altimétricos a fim de identificar qual das fontes que geraria a melhor modelagem para estimar o perigo à inundação no município de Jaguari. Dessa forma, com a implementação da metodologia, várias conclusões foram obtidas, algumas positivas e outras negativas.

Quanto ao cenário positivo, salienta-se a aplicação, de forma integral, da metodologia do trabalho. A atribuição de notas e pesos induziu o processo metodológico para um desfecho das áreas com maiores perigos à inundação de forma muito compatível com a realidade geográfica da área de estudo, visto que um dos autores é natural do município, e o mesmo já conviveu com cenários de inundação.

Negativamente é ressaltado a incompatibilidade da modelagem para as três ba- 
ses de dados, principalmente em relação a carta topográfica. Conforme destacado no decorrer do texto, a falta de informação altimétrica mostrou-se como um problema à modelagem dos dados oriundos dessa fonte de dados.

Tendo em vista a proposta inicial do trabalho, que era de identificar quais das fontes de dados altimétricos modelados seria o mais indicado para cartografar o perigo à inundação no município de Jaguari, optou-se em utilizar a mescla dos dados modelados com o SRTM e com o ASTER. O alto grau de correlação $\left(\mathrm{R}^{2}=0,931\right)$ obtido entre essas fontes mostraram-se incisivas para definir o perigo à inundação no município e compatíveis para com o objetivo do trabalho.

Os resultados obtidos, de forma geral, foram extremamente importantes, pois, a próxima etapa do referido trabalho, será a realização do levantamento planialtimétrico e cadastral, para posteriormente obter o mapa de vulnerabilidade, e com um novo MDE, realizar o cruzamento das inúmeras informações e obter o mapa de risco à inundação. Alerta-se que o referido levantamento, faz-se necessário ao trabalho, visto que o estudo é para uma área urbana, logo, o adensamento de informações altimétricas, faz-se de extrema importância para uma representação fidedigna com a da realidade.

Por fim, destaca-se que para o posterior mapeamento, será atribuída uma maior ênfase nos bairros denominados: Centro, Mauá, Nossa Senhora Aparecida, Promorar, Rivera e Sagrado Coração de Jesus, os quais registraram alerta de alto perigo à inundação com a metodologia aqui implantada.

\section{Agradecimentos}

Agradecemos à CAPES (Coordenação de Aperfeiçoamento de Pessoal de Nível Superior) pela concessão de bolsa de estudos ao primeiro autor.

\section{Referências}

ANA - Agência Nacional de Águas. Atlas de vulnerabilidade a inundações. Disponível em: <http://www.ana.gov.br/bibliotecavirtual/arquivos/20131002104753_Plotagem_RS_A0.pdf>. Acesso em 17 fev.14.

Cartografia no Rio Grande do Sul. Secretaria do Planejamento e Gestão, Departamento de Planejamento Governamental/DEPLAN, Florianópolis - I Reunião Plenária Fórum Regional Sul CONCAR. Disponível em: <http://www.concar.ibge.gov.br/PaginaForum/Forum_Sul/Apresentacoes/RIO\%20GRANDE\%20DO\%20SUL_CONCAR.pdf>. Acesso em 23 fev.2014.

COLOMBO, A; JUNQUEIRA, A. ANTUNES, M; PINHEIRO, T. Influência do tempo de inundação e do tamanho da árvore na emergência foliar de indivíduos de Pseudobombax munguba (Malvaceae) em uma área de várzea da Amazônia Central. Disponível em: <http:// pdbff.inpa.gov.br/cursos/efa/livro/2006/pdfs/vapo3g5.pdf>. Acesso em 17 fev.14.

Correio do Povo. Cerca de 30 famílias seguem desabrigadas em Jaguari. Postado dia 21 de janeiro de 2010 às 8:56h. Disponível em: <http://www.correiodopovo.com.br/Noticias/?Noticia=88280>. Acesso em 17 fev.14.

CUTTER, S. L.; PRESS, J. H. American Hazardscapes - The Regionalization of Hazards and Disasters. ISBN 0-309-07443-6. Copyright 2001 by the National Academy of Sciences. Printed in

Geografia Ensino \& Pesquisa, v. 18, n.2, p. 123-144, maio/ago. 2014

Prina, B. Z.; Trentin, R.

ISSN 2236-4994 
the United States of America. Disponível em: <http://www.inpe.br/crs/geodesastres/conteudo/ livros/Cutter_2001_American_hazardscapes.pdf>. Acesso em 25 set. 2013.

ECKHARDT, R. R. Geração de modelo cartográfico aplicado ao mapeamento das áreas sujeitas às inundações urbanas na cidade de Lajeado/RS. Dissertação submetida ao Programa de Pós- Graduação em Sensoriamento Remoto do Centro Estadual de Pesquisas em Sensoriamento Remoto - UFRGS. Disponível em: < http://www. ufrgs.br/srm/ppgsr/publicacoes/Dissert_RafaelEckhardt.pdf>. Acesso em 15 ago. 2013.

FAMURS. História do Município - Jaguari - RS. Portal municipal. Disponível em: <http:// www.portalmunicipal.org.br/entidades/famurs/municipio/historia.asp?iIdEnt $=5523 \& i I d M$ un $=100143208>$. Acesso em 17 fev.14.

FIGUEIRÊDO, M. C. B. de; VIEIRA, V. de P. P. B.;MOTA, S.; ROSA, M. de F.; MIRANDA, S. Análise da Vulnerabilidade Ambiental. Fortaleza/CE, Embrapa, 2010, ISSN 1677-1915, 47 p.. Disponível em: <http:// www.cnpat.embrapa.br/cnpat/cd/jss/acervo/Dc_127.pdf>. Acesso em 24 ago.2013.

GUIMARÃES, P. R. B. Métodos Quantitativos Estatísticos. IESDE Brasil S.A., 1. a edição, 2007, 245 p.

IBGE. Cidades Rio Grande do Sul - Jaguari - Censo Demográfico 2010 - Sinopse. Disponível em: $<$ http:/ / cidades.ibge.gov.br/xtras/temas.php?codmun=431110\&idtema $=1 \&$ search $=$ rio-grande-do-sul|jaguari|censo-demografico-2010:-sinopse->. Acesso em 24 nov.2013.

IBGE. Cidades Rio Grande do Sul - Jaguari. Disponível em: < http://www.ibge.gov.br/cidadesat/ xtras/perfil.php?codmun=431110>. Acesso em 24 nov.2013.

INSTITUTO DE PESQUISAS TECNOLÓGICAS (IPT). Mapeamento Geomorfológico do Estado de São Paulo. São Paulo. Escala 1:500.000, v. 2, 1981. 130 p.

JAGUARI. Prefeitura Municipal de Jaguari. Lei municipal no 1.825 de 22 de agosto de 1989. Denominação do Bairro Santa Rosa.

JAGUARI. Prefeitura Municipal de Jaguari. Lei municipal $\mathbf{n}^{\mathbf{o}} \mathbf{1 . 8 2 6}$ de 22 de agosto de 1989. Denominação do Bairro Rivera.

JAGUARI. Prefeitura Municipal de Jaguari. Lei municipal no 1.831 de 21 de setembro de 1989. Denominação do Bairro Nossa Senhora de Lourdes.

JAGUARI. Prefeitura Municipal de Jaguari. Lei municipal no 1.836 de 31 de outubro de 1989. Definição do Perímetro Urbano de Jaguari/RS.

JAGUARI. Prefeitura Municipal de Jaguari. Lei municipal no 2.075 de 10 de dezembro de 1996. Denominação do Bairro Consolata.

JAGUARI. Prefeitura Municipal de Jaguari. Lei municipal no 2.076 de 10 de dezembro de 1996. Denominação do Bairro Promorar.

JAGUARI. Prefeitura Municipal de Jaguari. Lei municipal no 2.153 de 16 de novembro de 1998. Denominação do Bairro Nossa Senhora Aparecida.

JAGUARI. Prefeitura Municipal de Jaguari. Lei municipal no 2.196 de 23 de dezembro de 1999. Denominação do Bairro Sagrado Coração de Jesus.

Geografia Ensino \& Pesquisa, v. 18, n.2, p. 123-144, maio/ago. 2014.

Uso de três fontes de dados altimétricos para identificação de áreas com perigos à inundação

JAGUARI. Prefeitura Municipal de Jaguari. Lei municipal no 2.515 de 14 de abril de 2005. Denominação do Bairro Mauá.

JHA, A. K; LAMOND, R. B. J. Cidades e Inundações - Um guia para a Gestão Integrada do Risco de Inundação Urbana para o Século XXI - Um Resumo para os Formuladores de Políticas. THE WORLD BANK - Editoração: Joaquin Toro e Frederico Ferreira Pedroso Banco Mundial / Escritório de Brasília - 2012. Disponível em: <http://www.gfdrr.org/sites/gfdrr.org/files/Portuguese_Cities_and_Flooding_Summary_Policy_Makers.pdf>. Acesso em 15 ago. 2013. 
nologias para mapeamento de áreas de risco de inundação em Guaçuí, ES: uma análise comparativa entre dois métodos. Cadernos de Geociências, v. 8, n. 2, novembro 2011. Disponível em: <http:// www.portalseer.ufba.br/index.php/cadgeoc/article/view/5288>. Acesso em 16 fev.2014.

MAGNANELLI, N. P. Perigo x Risco. Disponível em: < http://www.cvs.saude.sp.gov.br/up/7\%20-\%20Conceito $\% 20$ Risco $\% 20 \mathrm{X} \% 20$ Perigo $\% 20-\% 20 \mathrm{Neli} \% 20$ Pieres $\% 20$ Magnanelli $\% 20$ (DVST).pdf>. Acesso em 24 ago.2013.

NEMITZ, R. Diário de Santa Maria noticia a enchente em Jaguari. Postado dia 4 de outubro de 2012 às 13:34h. Disponível em: <http://www.rafaelnemitz.com/2012/10/diario-de-santa-maria-noticia-enchente.html>. Acesso em 17 fev.14.

OLIVEIRA, G. G. de; GUASSELLI, L. A. Relação entre a Suscetibilidade a Inundações e a Falta de Capacidade nos Condutos da Sub-bacia do Arroio da Areia, em Porto Alegre/RS. RBRH — Revista Brasileira de Recursos Hídricos,Volume 16 n.1 Jan/Mar 2011, 05-15. Disponível em: <http:// www.abrh.org.br/sgcv3/UserFiles/Sumarios/8753f3a854aff089d553dc3f0d6ddab6_4705edcea483 4fb460aa844414ab6135.pdf>. Acesso em 16 fev.2014.

PRINA, B. Z.; MIOLA, A. C. Mapa temático turístico urbano das belezas naturais do município de Jaguari, RS. In: SIMPÓSIO BRASILEIRO DE SENSORIAMENTO REMOTO, 15. (SBSR), 2011, Curitiba. Anais... São José dos Campos: INPE, 2011. p. 3796-3804. DVD, Internet. ISBN 978-85-17-00056-0 (Internet), 978-85-17-00057-7 (DVD). Disponível em: <http://urlib. net/3ERPFQRTRW/3A49AAS>. Acesso em: 26 ago. 2014.

RECKZIEGEL; B. W. Levantamento dos desastres desencadeados por eventos naturais adversos no estado do Rio Grande do Sul no período de 1980 a 2005. Dissertação de mestrado, Universidade Federal de Santa Maria - UFSM, 2007 - Volume I e II.

ROBAINA, L. E. de S.; TRENTIN, R (org.). Desastres Naturais no Rio Grande do Sul. ISBN: 978.85.7391-197-8, 376p. Editora UFSM. Santa Maria, 2013.

Sadeck - Geotecnologias. Dados SRTM (banda X) com 30 m de resolução espacial disponíveis para o Brasil. Disponível em: <http://geotecnologias.wordpress.com/2013/08/06/dados-srtm-banda-x-com-30-m-de-resolucao-espacial-disponiveis-para-o-brasil/>. Acesso em 23 fev.2014.

SANTOS, K. R. dos. Inundações urbanas: um passeio pela literatura. Rev. Geo. UEG - Goiânia, v.1, n.1, p.177-190, jan./jun. 2012. Disponível em: <http://www.prp.ueg.br/revista/index.php/elisee/ article/view/585/329>. Acesso em 05 out. 2013.

SANTOS, R. F. dos (org). Vulnerabilidade Ambiental: desastres naturais ou fenômenos induzidos? Brasília: Ministério do Meio Ambiente, 2007. Disponível em: <http://www.inpe.br/crs/geodesastres/conteudo/livros/Vulnerabilidade_ambiental_desastres_naturais_ou_fenomenos_induzidos_MMA_2007.pdf>. Acesso em 25 ago. 2013.

Sistema FAEP. Novo Código Florestal Brasileiro. Disponível em: <https://s3-sa-east-1.amazonaws.com/comunicacao/novo-codigo-florestal-principais-mudancas.pdf $>$. Acesso em 16 fev.2014.

SOUSA, A. Coeficiente de Correlação Linear de Pearson. Disponível em: < http://www.aurea. uac.pt/pdf_MBA/coef_correl_Pearson.pdf>. Acesso em 22 fev.2014.

SOUZA, G. M. de; MATRICARDI, E. A. T. Análise comparativa dos modelos de elevação SRTM, ASTER GDEM e TOPODATA para estimar o fator topográfico (LS) da USLE. Anais XVI Simpósio Brasileiro de Sensoriamento Remoto - SBSR, Foz do Iguaçu, PR, Brasil, 13 a 18 de abril de 2013, INPE. Disponível em: <http://www.dsr.inpe.br/sbsr2013/files/p0253.pdf>. Acesso em 17 fev.14.

TRENTIN, R. ROBAINA, L. E. de S. Análise do relevo no alto curso da bacia hidrográfica do Rio Itu, RS. Interface Porto Nacional/TO, v. 2, n. 2. p. 146-155, maio 2005. Disponível em: <http://revista.uft.edu.br/index.php/interface/article/view/339/236 >. Acesso em 16 fev.2014.

TUCCI, C. E. M.; BERTONI, J. C. (Org.) Inundações Urbanas da América do Sul. Porto Alegre: Associação Brasileira de Recursos Hídricos, 2003. Disponível em: < http://www.eclac.cl/sa$\mathrm{mtac} /$ noticias/documentosdetrabajo/5/23335/InBr02803.pdf>. Acesso em 25 ago. 2013.

Geografia Ensino \& Pesquisa, v. 18, n.2, p. 123-144, maio/ago. 2014

Prina, B. Z.; Trentin, R.

ISSN 2236-4994 143 


\section{Correspondência}

\section{Bruno Zucuni Prina}

E-mail: brunozprina@gmail.com

Recebido em 11 de abril de 2014.

Revisado pelo autor em 26 de julho de 2014 .

Aceito para publicação em 10 de agosto de 2014.

Geografia Ensino \& Pesquisa, v. 18, n.2, p. 123-144, maio/ago. 2014.

Uso de três fontes de dados altimétricos para identificação de áreas com perigos à inundação 